\title{
Pengembangan E-portofolio Tematik-Terpadu Berbasis Web Blog untuk Menanamkan Karakter Kritis dan Kreatif melalui Pembelajaran IPA
}

\author{
Arfilia Wijayanti ${ }^{1}$ dan Moh. Aniq Khairul Basyar ${ }^{2}$ \\ Universitas PGRI Semarang \\ email: arfiliaw11@gmail.com ${ }^{1}$, khairulbasyar@ymail.com ${ }^{2}$
}

\begin{abstract}
Abstrak
Penelitian ini bertujuan untuk mengembangkan e-portofolio tematik terpadu berbasis web blog untuk menanamkan karakter kritis dan kreatif melalui pembelajaran IPA mahasiswa calon guru SD. Metode yang digunakan adalah penelitian dan pengembangan $(R$ and $D)$ yang diarahkan untuk mengembangkan media $e$-portofolio tematik terpadu berbasis web blog yang tervalidasi dan teruji empirik mampu menumbuhkan karakter kritis dan kreatif mahasiswa. Instrumen yang digunakan berupa angket, serta lembar observasi. Teknik pengolahan data dilakukan meliputi observasi karakter kritis dan kreatif mahasiswa, angket respon mahasiswa, serta analisis dan kesimpulan. Produk media e-portofolio tematik terpadu berbasis web blog yang dikembangkan mendapat penilaian layak dari ahli. Hasil penerapan media e-portofolio tematik terpadu berbasis web blog menunjukkan bahwa media e-portofolio tematik terpadu berbasis web blog yang dikembangkan dapat menumbuhkan karakter kritis dan kreatif mahasiswa calon guru SD.
\end{abstract}

Keywords: e-portofolio; tematik terpadu; berbasis web blogkarakter kritis dan kreatif, pembelajaran IPA.

\section{PENDAHULUAN}

Karakter manusia telah melekat pada kepribadian seseorang dan ditunjukkan dalam perilaku kehidupannya sehari-hari. Sejak lahir, manusia telah memiliki potensi karakter yang ditunjukkan oleh kemampuan kognitif dan sifat-sifat bawaannya. Karakter bawaan akan berkembang jika mendapat sentuhan pengalaman belajar dari lingkungannya. Pesatnya perkembangan sains dan teknologi dan informasi, menuntut manusia untuk semakin kritis dan kreatif dalam menyesuaikan diri dalam segala aspek kehidupan. Aspek pendidikan salah satunya, merupakan aspek yang sangat menentukan maju mundurnya suatu kehidupan yang semakin ketat persaingannya. Dengan demikian proses pendidikan diharapkan mampu mengembangkan teknologi dan juga membentuk manusia yang berkarakter kritis dan kreatif.

Pembinaan karakter khususnya karakter kritis dan kreatif penting untuk terus menerus dilakukan secara holistik dari semua lingkungan pendidikan yaitu keluarga, sekolah, dan masyarakat. Menurut Miftahudin (2010) pendidikan karakter pada usia dini di keluarga bertujuan untuk pembentukan, pada usia remaja di sekolah bertujuan untuk pengembangan sedangkan pada usia dewasa di bangku kuliah bertujuan untuk pemantapan. Tugas-tugas pendidik adalah menyediakan lingkungan belajar yang baik untuk membentuk, mengembangkan dan memantapkan karakter peserta didiknya. 
Perilaku karakter peserta didik hendaknya teramati perkembangannya dari waktu ke waktu. Tuntutan sistem pengolahan hasil penilaian dan pelaporan hasil belajar seharusnya tidak hanya mengutamakan keterampilan sebagai prioritas pencapaian hasil belajar. Sehingga perilaku-perilaku peserta didik yang menyimpang dari semestinya sebagai seorang pelajar tidak terjadi. Perilaku yang menyimpang yang teramati biasanya menyontek pada waktu ujian dan mengerjakan tugas, bersikap kurang sopan santun, mudah menyerah, merasa tidak mampu sebelum mencoba, tidak mau menjadi kreatif dan tidak kritis terhadap maslah. Disamping itu, aktivitas peserta didik dalam mengikuti kegiatan belajar mengajar cenderung pasif, tidak ada pertanyaan-pertanyaan yang diajukan oleh peserta didik dan rendahnya partisipasi peserta didik dalam menyimak atau mendiskusikan materi yang disampaiakan.

Salah satu upaya untuk mengatasi masalah tersebut adalah berupa penerapan media pembelajaran sekaligus berfungsi sebagai alat penilaian otentik yang menilai dan memonitor semua ranah hasil belajar (yang tercakup dalam ranah sikap baik religius maupun sosial, ranah pengetahuan, dan ranah keterampilan), dapat mengendalikan perilaku menyimpang peserta didik serta mampu meningkatkan aktivitas dan partisipasi peserta didik dalam kegiatan belajar mengajar. Media pembelajaran yang dimaksud adalah portofolio. Dengan menerapkan media portofolio ini, diharapkan dapat mengakomodasi fungsi, tujuan serta prinsip-prinsip pembelajaran dan juga memberi tambahan informasi bagi pendidik dalam merancang alternatif penilaian yang ideal. Berdasarkan uraian tersebut maka peneliti mengembangkan media e-portofolio tematik terpadu berbasis web blog untuk menanamkan nilai-nilai karakter mahasiswa calon guru SD. Peneliti memfokuskan mengembangan media pembelajaran tematik-terpadu on-line berbasis web blog untuk meningkatkan karakter kritis dan kreatif mahasiswa calon guru SD melalui perkuliahan mata kuliah Perencanaan Pembelajaran SD di Program Studi Pendidikan Guru SD (PGSD) Fakultas Ilmu Pendidikan (FIP) Universitas PGRI Semarang.

\section{METODE PENELITIAN}

Penelitian ini merupakan penelitian pengembangan (Development Research) yang diarahkan untuk mengembangkan media e-portofolio tematik terpadu berbasis web blog untuk menanamkan karakter kritis dan kreatif mahasiswa calon guru SD. Penelitian ini dilakukan di Program Studi Pendidikan Guru SD (PGSD) FIP UPGRIS yang menyiapkan calon guru SD sebagai tempat pengambilan data, analisis data, dan interpretasi hasil penelitian. Penelitian dilakukan pada semester gasal tahun 2015/2016, sebagai populasi adalah mahasiswa semester 5, sebagai sampel diambil kelas 5E. Tahapan penelitian meliputi 
uji coba, revisi, verifikasi, implementasi, revisi lanjut, verifikasi lanjut, pengolahan data, analisis, diskusi, dan menyimpulkan hasil. Model pengembangan mengikuti langkah-langkah kerja pengembangan yang telah dikemukakan oleh Borg \& Gall, (1983.

Pengumpulan data dalam penelitian ini menggunakan metode sebagai berikut:

1. Angket

Angket digunakan untuk memperoleh data validasi yang berbertujuan untuk mendapatkan data kelayakan media e-portofolio tematik-terpadu berbasis web blog untuk mengungkap dan meningkatkan karakter kritis dan kreatif mahasiswa dari ahli. Selain itu, angket juga digunakan untuk mengumpulkan informasi mengenai tanggapan mahasiswa tentang media e-portofolio tematik-terpadu berbasis web-blog. Hasil tanggapan ahli yang diperoleh melalui lembar angket dihitung persentasenya, kemudian dihitung dengan membagi skor yang diperoleh dengan skor maksimal dikalikan 100\%. Hasil persentase diinterpretasikan ke dalam kriteria-kriteria yang ditetapkan pada Tabel 1.

Tabel 1 Kriteria Persentase Skor Penilaian kelayakan Media E-Portofolio Tematik Terpadu

\begin{tabular}{cc}
\hline Interval Persentase skor & Kriteria \\
\hline $81 \%-100 \%$ & Sangat Baik \\
$61 \%-80 \%$ & Baik \\
$41 \%-60 \%$ & Cukup \\
$21 \%-40 \%$ & Kurang Baik \\
$<20 \%$ & Tidak Baik \\
\hline
\end{tabular}

2. Lembar Pengamatan Karakter Kritis dan Kreatif Mahasiswa

Hasil penerapan media e-portofolio tematik terpadu berbasis web blog yang dianalisis pada aspek peningkatan karakter kritis dan kreatif mahasiswa diperoleh dari hasil observasi awal dan akhir. Peningkatan karakter kritis dan kreatif mahasiswa sesuai dengan kriteria peningkatan gain $(g)$ Hake seperti pada Tabel 2.

Tabel 2 Kriteria Peningkatan Sikap Kritis dan Kreatif

\begin{tabular}{ccc}
\hline No & Nilai gain & Kriteria \\
\hline 1 & $\mathrm{~g} \leq 0,3$ & kurang \\
2 & $0,3 \leq \mathrm{g} \leq 0,7$ & sedang \\
3 & $\mathrm{~g} \geq 0,7$ & tinggi \\
\hline
\end{tabular}


Data hasil pengamatan dan angket respon siswa dianalisis secara deskriptif dengan disajikan dalam persentase menurut kategori sesuai Tabel 3.

Tabel 3 Kategori Karakter Kritis dan Kreatif

\begin{tabular}{cc}
\hline Interval skor $\%$ & Kriteria \\
\hline $81,25<$ skor $\leq 100,00$ & MK (Membudidaya) \\
$62,50<$ skor $\leq 81,25$ & MB (Mulai Berkembang) \\
$43,75<$ skor $\leq 62,50$ & MT (Mulai Terlihat) \\
$25,00<$ skor $\leq 43,75$ & BT (Belum Terlihat) \\
\hline
\end{tabular}

3. Lembar Penilian diri (Self Assesment)

Metode ini dilakukan untuk mendapatkan informasi tanggapan mahasiswa terhadap penerapan e-portofolio dalam pembelajaran.

Metode analisis data yang dilakukan meliputi penentuan batas ketercapaian literasi sains dan peningkatan, pemberian skor setiap soal, pengubahan skor menjadi nilai, pengelompokkan subyek penelitan berdasarkan nilai yang diperoleh, serta analisis dan kesimpulan.

\section{HASIL DAN PEMBAHASAN}

\section{Validasi Media E-Portofolio Tematik Terpadu Berbasis Web Blog}

Uji kelayakan media e-portofolio dilakukan oleh ahli yang ditunjuk dan memiliki kompetensi di bidangnya. Hasil validasi yang berupa saran dan komentar digunakan sebagai acuan untuk memperbaiki media e-portofolio yang dikembangkan. Selanjutnya, dilakukan validasi kembali dan dianalisis sehingga diperoleh skor rata-rata berdasarkan hasil bagi skor yang diperoleh dengan skor maksimal. Validasi media e-portofolio pada penelitian ini meliputi validasi terhadap desain dan produk. Validasi dilakukan oleh ahli dengan hasil sebagai berikut:

1. Validasi Desain

Berdasarkan hasil angket kelayakan desain oleh ahli didapatkan nilai yang tersaji pada Tabel 4. 
Tabel 4 Rekapitulasi Data Validasi oleh Ahli terhadap Desain E-Portofolio Tematik Terpadu

\begin{tabular}{clcc}
\hline No & \multicolumn{1}{c}{ Validator } & Rata-Rata & Kriteria \\
\hline 1 & Ahli Media & 3,88 & layak \\
2 & Ahli Pendidikan Karakter & 3,94 & layak \\
\hline
\end{tabular}

Berdasarkan hasil penilaian menggunakan angket oleh ahli didapatkan nilai persentase kelayakan desain media yaitu 95,82\% maka masuk pada kriteria sangat baik, sehingga desain dapat diteruskan untuk dapat dibuat dengan perbaikan yaitu pada aspek jenis dan ukuran huruf, dan penataan link produk web blog mahasiswa pada main web blog $e$ portofolio yang dikembangkan. Peneliti melakukan perbaikan sesuai dengan saran dari validator, dan setelah dilakukan beberapa kali diskusi dan refleksi, akhirnya ahli memberikan rekomendasi baik dan valid terhadap produk media e-portofolio yang telah dikembangkan.

\section{Validasi Produk}

Kelayakan produk didapatkan melalui penilaian ahli menggunakan angket yang dikembangkan peneliti. Hasil validasi ahli terhadap Produk e-portofolio tersaji pada Tabel 5.

Tabel 5 Rekapitulasi Hasil Validasi oleh Ahli terhadap Produk E-Portofolio Tematik Terpadu

\begin{tabular}{clcc}
\hline No & \multicolumn{1}{c}{ Validator } & Rata-Rata & Kriteria \\
\hline 1 & Ahli Media & 3.94 & layak \\
2 & Ahli Pendidikan Karakter & 3.96 & layak \\
\hline
\end{tabular}

Seluruh aspek yang dinilai baik oleh ahli media maupun ahli pendidikan karakter terhadap produk media e-portofolio didapatkan rata-rata 3.95, menunjukkan bahwa produk dapat diimplementasikan.

\section{Penerapan Media E-Portofolio Tematik Terpadu Berbasis Web Blog}

Penerapan media e-portofolio tematik terpadu berbasis web blog dimaksudkan untuk mengetahui efektivitas penggunaan media yang dikembangkan dengan indikator mampu menumbuhkan karakter kritis maupun kreatif mahasiswa calon guru SD. Penerapan produk media e-portofolio tematik terpadu berbasis web blog dilakukan secara eksperimen yaitu preeksperimental desain model one-shot case study. Uji coba dilakukan pada perkuliahan Perencanaan Pembelajaran SD dengan sampel sebanyak 45 orang mahasiswa. 
Hasil observasi terhadap implementasi e-portofolio terhadap peningkatan karakter kritis dan kreatif mahasiswa ditunjukkan pada Tabel 6.

Tabel 6 Hasil Observasi Implementasi Media E-Portofolio Tematik Terpadu terhadap peningkatan karakter kritis dan kreatif mahasiswa

\begin{tabular}{|c|c|c|c|c|c|c|c|c|c|c|c|}
\hline \multirow{2}{*}{$\begin{array}{c}\text { Rata-rata } \\
\text { Skor }\end{array}$} & \multicolumn{9}{|c|}{ Nomor indikator Karakter Kritis dan Kreatif Mahasiswa } & \multirow[b]{2}{*}{ Total } & \multirow[b]{2}{*}{$\%$} \\
\hline & 1 & 2 & 3 & 4 & 5 & 6 & 7 & 8 & 9 & & \\
\hline $\begin{array}{c}\text { Observasi } \\
\text { Awal }\end{array}$ & 2 & 2 & 1 & 1 & 2 & 2 & 1 & 2 & 1 & 14 & 38,89 \\
\hline $\begin{array}{c}\text { Observasi } \\
\text { Akhir }\end{array}$ & 4 & 4 & 4 & 4 & 3 & 4 & 4 & 3 & 3 & 33 & 91,67 \\
\hline$n-$ & $\imath \mathrm{ra}$ & & & & & & & & & siswa & 0,86 \\
\hline
\end{tabular}

Keterangan indikator karakter kritis, yaitu:

(1) Mampu mencari penjelasan berdasarkan teori dan pertanyaan

(2) Mampu memberikan alasan

(3) Mampu mencoba tetap relevan dengan ide utama

(4) Mampu menjaga ide dasar dan orisinil dalam pikiran

(5) Mampu mengambil keputusan ketika bukti-bukti dan alasan memungkinkan untuk melakuka

Keterangan indikator karakter kreatif (Torrance, 1969), yaitu:

(6) Fluency (kelancaran), adalah kemampuan untuk menghasilkan banyak gagasan

(7) Fleksibility (keluwesan), adalah kemampuan untuk mengemukakan bermacam-macam pemecahan atau pendekatan terhadap masalah

(8) Originality (keaslian), adalah kemampuan untuk mencetus gagasan dengan cara asli dan tidak klise

(9) Elaboration (penguraian), adalah kemampuan untuk menguraikan sesuatu secara lebih rinci

Hasil pada Tabel 6 menunjukkan bahwa rata-rata total skor akhir indikator karakter kritis dan kreatif adalah 91,67 \% yaitu telah menunjukkan kriteria membudidaya (MK) dikalangan mahasiswa. Hal ini menunjukkan bahwa penggunaan media e-portofolio tematik terpadu berbasis web blog dapat membudayakan karakter kritis mahasiswa. Peningkatan karakter kritis dan kreatif mahasiswa pun tergolong tinggi yaitu dengan nilai n-gain 0,86. 
Seluruh aspek keterampilan berpikir kritis yang diobservasi mengalami peningkatan dari observasi awal dan akhir. Pada aspek mencari penjelasan, memberi alasan, mencoba tetap relevan dan menjaga ide menunjukkan skala maksimal seperti yang ditunjukkan oleh Tabel 6. Aspek menjaga ide dasar dan orisinalitas dalam berpikir menduduki peringkat terbawah dan termasuk dalam kategori sedang.

Setiap aspek keterampilan berpikir kreatif mahasiswa mengalami peningkatan seperti yang ditampilkan pada Tabel 6. Dalam menyelesaikan permasalahan saat pembelajaran maupun tugas tipe fluency dan flexibility, mahasiswa memperoleh skor maksimum, aspek ini juga memiliki peningkatan yang tertinggi. Aspek originality memiliki peningkatan gain yang terendah. Sebagian besar mahasiswa masih mengalami kesulitan dalam menyelesaikan permasahan maupun tugas secara originality. Hal tersebut dimungkinkan karena mahasiswa masih berkutat pada proses penghafalan materi sehingga kemampuan mereka untuk berinovasi atau berimajinasi menciptakan suatu gagasan yang baru masih lemah.

Indikator yang hampir sama pada aspek berpikir kritis dan kreatif yaitu aspek menjaga ide dasar dan orisinil dalam berpikir (keterampilan berpikir kritis) dan originality (keterampilan berpikir kritis). Keterkaitan antar kedua aspek ini dikarenakan pada aspek menjaga ide dasar dan orisinil dalam berpikir terkait dengan aspek originality. Menurut Rabari et al. (2011), Seorang individu kreatif menunjukkan kemampuan berpikir kritis yang tinggi. Berpikir kreatif memunculkan rasa tidak puas untuk mensintesis suatu fenomena yang terlahir melalui pemikiran kritis. Berpikir kritis memilih solusi yang paling tepat berdasarkan solusi ganda dari pemikiran kreatif. Melalui proses tersebut tampak bahwa berpikir kritis tumbuh dalam simpati dengan berpikir kreatif dan sebaliknya.

Pembelajaran IPA dengan media e-portofolio tematik terpadu berbasis web blog bermuatan karakter pada dasarnya adalah suatu usaha penilaian yang dilakukan oleh dosen agar mahasiswa memiliki kemampuan mengungkapkan dan mengekspresikan dirinya dengan memunculkan nilai-nilai sikap agar menjadi sebuah kebiasaan dan karakter yang ada pada mahasiswa calon guru SD. Penilaian ditunjukkan dengan aspek-aspek nilai karakter yang dimunculkan mahasiswa disetiap pertemuan selama penelitian. Penilaian perilaku berkarakter ini berdasarkan nilai-nilai sikap yang sesuai dengan prinsip pembelajaran menggunakan media e-portofolio tematik terpadu yaitu karakter kritis dan kreatif yang tertuang pada indikator keterampilan berpikir kritis dan kreatif. Adanya peningkatan dan pembudayaan karakter kritis dan kreatif mahasiswa menunjukkan bahwa menerapkan pembelajaran dengan media e-portofolio dapat meningkatkan perilaku berkarakter mahasiswa calon guru. Hal ini membuktikan bahwa media e-portofolio tematik terpadu berbasis web blog menunjukkan 
indikator kinerja atau indikator keberhasilan dalam penelitian ini telah tercapai. Hasil ini sejalan dengan penelitian yang dilakukan Yankumara \& Arsana (2014), pembelajaran portofolio berbasis karakter dapat meningkatkan hasil belajar peserta didik.

\section{Respon Mahasiswa dalam Mengikuti Perkuliahan dengan Menggunakan Media E- Portofolio Tematik Terpadu}

Hasil angket tanggapan mahasiswa selama mengikuti perkuliahan terhadap implementasi media e-portofolio tematik terpadu disajikan pada Tabel 7.

Tabel 7 Tanggapan Mahasiswa terhadap Implementasi Asesmen Autentik E-Portofolio Berbasis Web Blog

\begin{tabular}{|c|c|c|c|}
\hline \multirow[t]{2}{*}{ No } & \multirow[t]{2}{*}{ Kriteria Penilaian } & \multicolumn{2}{|c|}{ Tanggapan } \\
\hline & & $\mathrm{Ya}$ & Tidak \\
\hline 1 & $\begin{array}{l}\text { Saya menyukai tampilan warna, ukuran dan jenis } \\
\text { huruf pada website } e \text {-portofolio tematik terpadu }\end{array}$ & 96 & 4 \\
\hline 2 & $\begin{array}{l}\text { Saya dapat dan mudah mengakses website } e \text { - } \\
\text { portofolio tematik terpadu dengan lancar }\end{array}$ & 100 & 0 \\
\hline 3 & Link pada web blog berfungsi dengan baik & 100 & 0 \\
\hline 4 & $\begin{array}{l}\text { Menurut saya konten sains sudah merujuk pada } \\
\text { konsep-konsep yang diperlukan untuk memahami } \\
\text { fenomena alam dan perubahan yang dilakukan } \\
\text { terhadap alam melalui aktivitas manusia }\end{array}$ & 94 & 6 \\
\hline 5 & $\begin{array}{l}\text { Menurut saya proses sains sudah merujuk pada proses } \\
\text { mental yang terlibat ketika menjawab suatu } \\
\text { pertanyaan atau memecahkan masalah, seperti } \\
\text { mengidentifikasi dan menginterpretasi bukti serta } \\
\text { menerangkan kesimpulan }\end{array}$ & 95 & 5 \\
\hline 6 & $\begin{array}{l}\text { Menurut saya konteks aplikasi sains sudah relevan } \\
\text { dengan kurikulum pendidikan sains di negara } \\
\text { Indonesia }\end{array}$ & 96 & 4 \\
\hline 7 & $\begin{array}{l}\text { Saya senang dalam mengikuti dan mengerjakan tugas } \\
\text { pada e-portofolio selama perkuliahan }\end{array}$ & 99 & 1 \\
\hline & Persentase tanggapan $(\%)$ & 97,14 & 2,86 \\
\hline
\end{tabular}


Berdasarkan Tabel 7 dapat dinyatakan bahwa mahasiswa secara umum yaitu 97,14\% memberikan tanggapan baik terhadap implementasi media e-portofolio tematik terpadu. Hal ini dikarenakan penerapan media e-portofolio tematik terpadu mengubah peran mahasiswa dalam proses perkuliahan, dari sifat pasif menjadi partisipan aktif, mahasiswa aktif berkolaborasi untuk bekerjasama dan dapat berpartisipasi dalam membudayakan karakter kristis dan kreatif.

\section{KESIMPULAN}

Produk media e-portofolio tematik terpadu berbasis web blog yang dikembangkan mendapat penilaian layak dari ahli. Hasil penerapan media e-portofolio tematik terpadu berbasis web blog pada pembelajaran IPA menunjukkan bahwa media e-portofolio tematik terpadu berbasis web blog yang dikembangkan mampu memfasilitasi pembudayaan karakter kritis dan kreatif mahasiswa calon guru SD.

\section{DAFTAR PUSTAKA}

Alter, F. 2009. Understanding the Role of Critical and Creative Thinking in Australian Primary School Visual Arts Education. International Art in Early Chilhood Research Journal. 1 (1): 1-11.

Baker, M \& R. Rudd. 2001. Relationship between Critical and Creative Thinking. Journal of Southern Agricultural Education Research. 51(1): 173-188.

Borg, W.R.A., \& Gall, M.D. (1983). Educational Research: An Introduction $\left(4^{\text {th }} e d\right)$. Boston: Pearson Education, Inc.

Cheng, G. 2008. Implementation Challenges of The English Language Eportfolio System from Various Stakeholder Perspectives. Journal Educational Technology Systems, Vol. 37(1) 97-118, 2008-2009.

Danielson, C., \& Abrutyn, L. 1997 An Introduction to Using Portfolios in The Classroom. Alexandria, VA: Association for Supervision and Curriculum Development.

Dudeney, G. dan Hockly. N. 2007. How to Teach English with Technology. Pearson, Longman.

Hake, R.R. 2002. "Physics First: Opening Battle in the War on Science/Math Illiteracy?" Submitted to the American Journal of Physics on 27 June 2002; online as ref. 20 at < http://physics.indiana.edu/ hake/>.

Miftahudin. (2010). Implementasi pendidikan karakter di SMK Roudlotul Mubtadiin. Makalah disampaikan dalam seminar nasional: Strategi dan Implementasi Pendidikan Karakter Bangsa di Tingkat Satuan Pendidikan, Balitbang Kemendiknas, Tanggal 2829 Agustus 2010.

Moritz J. dan Christie, A. 2006. It's Elementary! Using Electronic Portfolios with Young Students. Tersedia http://electronicportfolios.com/portfolios/

Rabari, J. A., F. C., Indoshi \& T. Okwach. 2011. Correlates of Divergent Thinking Among Secondary School Physics Students. International Research Journals. 2(3): 982-996.

Rollins, T. J., 1990. Levels of Critical Thinking of Secondary Agriculture Students. Journal of Agriculture Education. 31(3): 47-53. Tersedia di http://www.jae- 
online.org/attachments/article/786/Rollins,\%20T_Vol31_3_47-53.pdf [diakses 26-122011].

Taufiq, M. dan Wijayanti, A. 2014. Pembelajaran IPA di SD dengan pendekatan saintifik dalam konteks dan Konten kurikulum 2013. Prosiding Seminar Nasional IPA V FMIPA UNNES. (Hal: 434-438)

Yankumara, R.T. \& arsana, I. M. 2014. Penerapan pembelajaran dengan portofolio berbasis karakter untuk meningkatkan hasil belajar mata pelajaran teknik listrik dasar otomotif di SMK Negeri 1 Purwoasri. JTM, 03 (2), 114 - 118. 